\title{
The Role of Copper in the Regulation of Ferroportin Expression in Macrophages
}

\author{
Aneta Jończy *(D), Rafał Mazgaj (D), Ewa Smuda, Beata Żelazowska, Zuzanna Kopeć (D), Rafał Radosław Starzyński \\ and Paweł Lipiński *
}

check for

updates

Citation: Jończy, A.; Mazgaj, R.;

Smuda, E.; Żelazowska, B.; Kopeć, Z.;

Starzyński, R.R.; Lipiński, P. The Role

of Copper in the Regulation of

Ferroportin Expression in

Macrophages. Cells 2021, 10, 2259.

https://doi.org/10.3390/cells10092259

Academic Editor: Alexander

E. Kalyuzhny

Received: 2 August 2021

Accepted: 24 August 2021

Published: 31 August 2021

Publisher's Note: MDPI stays neutral with regard to jurisdictional claims in published maps and institutional affiliations.

Copyright: (C) 2021 by the authors. Licensee MDPI, Basel, Switzerland. This article is an open access article distributed under the terms and conditions of the Creative Commons Attribution (CC BY) license (https:/ / creativecommons.org/licenses/by/ $4.0 /)$.
Department of Molecular Biology, Institute of Genetics and Animal Biotechnology, Polish Academy of Sciences, 05-552 Jastrzębiec, Poland; r.mazgaj@igbzpan.pl (R.M.); e.smuda@igbzpan.pl (E.S.);

b.zelazowska@igbzpan.pl (B.Ż.); z.kopec@igbzpan.pl (Z.K.); r.starzynski@igbzpan.pl (R.R.S.)

* Correspondence: a.jonczy@igbzpan.pl (A.J.); p.lipinski@igbzpan.pl (P.L.); Tel.: +48-227367058 (A.J.); $+48-227367046$ (P.L.)

\begin{abstract}
The critical function of ferroportin (Fpn) in maintaining iron homeostasis requires complex and multilevel control of its expression. Besides iron-dependent cellular and systemic control of Fpn expression, other metals also seem to be involved in regulating the Fpn gene. Here, we found that copper loading significantly enhanced Fpn transcription in an Nrf2-dependent manner in primary bone-marrow-derived macrophages (BMDMs). However, prolonged copper loading resulted in decreased Fpn protein abundance. Moreover, $\mathrm{CuCl}_{2}$ treatment induced Fpn expression in RAW 264.7 macrophages at both the mRNA and protein level. These data suggest that cell-typespecific regulations have an impact on Fpn protein stability after copper loading. Transcriptional suppression of Fpn after lipopolysaccharide (LPS) treatment contributes to increased iron storage inside macrophages and may result in anemia of inflammation. Here, we observed that in both primary BMDMs and RAW 264.7 macrophages, LPS treatment significantly decreased Fpn mRNA levels, but concomitant $\mathrm{CuCl}_{2}$ stimulation counteracted the transcriptional suppression of Fpn and restored its expression to the control level. Overall, we show that copper loading significantly enhances Fpn transcription in macrophages, while Fpn protein abundance in response to $\mathrm{CuCl}_{2}$ treatment, depending on macrophage type and factors specific to the macrophage population, can influence Fpn regulation in response to copper loading.
\end{abstract}

Keywords: ferroportin; copper; macrophages; Nrf2; LPS

\section{Introduction}

Ferroportin (Fpn) is the only known mammalian iron exporter, and it plays a vital role in the process of iron absorption from duodenal enterocytes and the reutilization of this microelement from senescent erythrocytes by reticuloendothelial macrophages. Due to its unique function in iron metabolism, Fpn expression remains under tight and complex control at the transcriptional, post-transcriptional, and posttranslational level [1]. Moreover, local and cell-type-specific Fpn regulation seems to be critical for maintaining iron homeostasis [2].

Fpn post-transcriptional regulation involves the interaction of iron regulator proteins (IRP1/2) with iron responsive element (IRE) sequences within the 5' UTR of Fpn mRNA [3]. At the protein level, Fpn is strongly downregulated by hepcidin (a peptide produced mainly by the liver in response to increased iron content), which triggers its internalization and degradation [4]. Transcriptional Fpn regulation involves the heme-dependent binding of transcriptional repressors (Bach1) or activators (Nrf2) to antioxidant response element (ARE) sequences localized within the Fpn promoter, highlighting the role of heme in the process [5,6]. It has been shown that iron itself can also increase Fpn transcription in macrophages and lung epithelial cells [7-9]. Interestingly, Fpn expression in macrophages was also increased upon loading with other metals, such as cadmium, cobalt, copper, 
manganese, and zinc. $\mathrm{Zn}$ and $\mathrm{Cd}$ are able to induce $\mathrm{Fpn}$ transcription by eliciting metal transcription factor-1 (MTF-1) translocation into the nucleus [9]. In macrophages, copper can stimulate Fpn expression at both the mRNA and protein level, as has been shown in the J774 macrophage cell line [10]. Although biological copper-iron interactions involved in processes of absorption, storage, and redistribution of these metals were described years ago [11], their detailed molecular mechanisms are still not fully elucidated. Therefore, the first aim of this study was to determine the possible molecular mechanisms of the regulation of Fpn expression by copper in macrophages, which plays a crucial role in systemic iron turnover.

Macrophages are pivotal components of the immune system, serving as key modulators and effectors of immune response, and are highly present in the chronic and acute inflammatory milieu [12]. One of the specific features of pro-inflammatory macrophages is iron retention within the cells as a result of the downregulation of Fpn expression and increased intracellular levels of ferritin, an iron storage protein $[13,14]$. This mechanism leads to reduced iron concentration in the plasma, and thus limits iron availability for extracellular pathogens, but at the same time decreases the iron supply for erythropoiesis, which contributes to the appearance of so-called anemia of infection (AI) or anemia of chronic diseases (ACD), the most prevalent anemias in hospitalized patients and the second most frequent type after iron-deficiency anemia [15,16]. Lipopolysaccharide (LPS), a component of the cell wall of Gram-negative bacteria, triggers the release of inflammatory cytokines in macrophages [17]. Previous studies reported that LPS treatment significantly downregulated Fpn expression in monocytic cells [18], but the mechanism is only partially understood. Interestingly, Nrf2 activation (transcription factor, nuclear factor, erythroid 2 like 2) during inflammation can counteract lipopolysaccharide-induced suppression of Fpn mRNA and enhance iron efflux in macrophages [19], suggesting that the regulation of Fpn expression by Nrf2 may contribute to anti-inflammatory processes.

It is well known that serum copper levels increase under a variety of inflammatory conditions $[20,21]$, and stimulating macrophages with LPS significantly influences the expression of copper-related genes, such as cellular copper importer (Ctr1) and the P1Btype ATPase responsible for delivering copper into cellular compartments (Atp7a) [22,23]. This study aims to illuminate the role of copper in the regulation of Fpn expression in macrophages and test the hypothesis that assumes the stimulation of Fpn expression by $\mathrm{Cu}$ ions at least partially counterbalances the mechanism leading to decreased Fpn levels and, consequently, iron retention within macrophages under LPS activation.

\section{Materials and Methods}

\subsection{Cell Culture}

\subsubsection{Bone-Marrow-Derived Macrophages (BMDMs)}

BMDMs were isolated from tibias, femurs, and humeri of 3-to-5-month-old male wild-type (C57Bl/6J) or Nrf2 knockout (B6.129CX1-Nfe2l2tm1Ywk/J) mice derived from Jackson Laboratory (Bar Harbor, ME, USA). Cells were seeded in $10 \mathrm{~cm}$ diameter Petri dishes for protein extraction, 6-well plates for RNA isolation, and rounded coverslips for confocal imaging. BMDMs were cultured in RPMI 1640 medium with L-glutamine and $25 \mathrm{mM}$ HEPES buffer (Gibco, Thermo Fisher Scientific, Waltham, MA, USA) supplemented with 10\% heat-inactivated FBS (EURx, Gdańsk, Poland), 10\% LCCM (L929-cell conditioned medium as a source of macrophage colony-stimulating factor), and $1 \%$ penicillin/streptomycin (Sigma-Aldrich, Burlington, MA, USA) at $37^{\circ} \mathrm{C}$, in $5 \% \mathrm{CO}_{2}$ and $21 \%$ $\mathrm{O}_{2}$ atmosphere.

\subsubsection{Peritoneal Macrophages}

Mouse primary peritoneal macrophages were isolated as previously described [24]. Briefly, 3-to-5-month-old male mice were euthanized with $\mathrm{CO}_{2}$, followed by surgical exposure of the inner skin lining the peritoneal cavity. Ice-cold PBS $(5 \mathrm{~mL})$ supplemented with 3\% FCS was injected into the peritoneal cavity using a $27 \mathrm{G}$ needle, then gentle 
massage of the peritoneum was performed to dislodge attached cells into the PBS solution. The fluid was carefully collected to avoid clogging by fatty tissue or other organs. Cell suspension was centrifuged at $800 \times g$ for $8 \mathrm{~min}$ and cell pellets were resuspended in the culture medium used for BMDM culture. Cells were seeded in 24-well cell culture plates for In-Cell Western blot analysis or 6-well plates for RNA isolation.

\subsubsection{RAW 264.7 Cell Line}

RAW 264.7 murine macrophages were obtained from the American Type Culture Collection (Rockville, MD, USA). Cells were cultured in DMEM (Gibco, Thermo Fisher Scientific, Waltham, MA, USA) containing 5\% $(v / v)$ FBS and $50 \mu \mathrm{g} / \mathrm{mL}$ gentamicin (SigmaAldrich, Burlington, MA, USA) in $175 \mathrm{~cm}^{2}$ plastic culture flasks for protein and 6-well plates for RNA isolation.

\subsection{Cytotoxicity Assay and ROS Production Measurements}

The CellTox ${ }^{\mathrm{TM}}$ Green Cytotoxicity Assay (Promega, Madison, WI, USA) was used to assess cytotoxic effects of dose- and time-dependent $\mathrm{CuCl}_{2}$ stimulation of BMDMs via real-time measurement of changes in membrane integrity occurring as a result of cell death. BMDMs were seeded in 96-well plates, incubated with $\mathrm{CuCl}_{2}(25-500 \mu \mathrm{M})$ for 8-24 h, and mixed with CellTox ${ }^{\mathrm{TM}}$ Green Dye according to the manufacturer's instructions. Fluorescence was measured using the BMG Fluostar microplate reader (Ex: $485 \mathrm{~nm}$, Em: $520 \mathrm{~nm})$.

Reactive oxygen species (ROS) production in $\mathrm{BMDMs}$ treated with $\mathrm{CuCl}_{2}$ was assessed using a chemically reduced form of fluorescein $\left(\mathrm{H}_{2}\right.$ DCFDA) (Thermo Fisher Scientific, Waltham, MA, USA). Upon cleavage of the acetate groups by intracellular esterases and oxidation, the non-fluorescent $\mathrm{H}_{2}$ DCFDA is converted to fluorescent $2^{\prime}, 7^{\prime}$-dichlorofluorescein (DCF). After $\mathrm{CuCl}_{2}$ treatment, BMDMs were incubated with $5 \mu \mathrm{M} \mathrm{H}_{2} \mathrm{DCFDA}$ probe for $30 \mathrm{~min}$, followed by staining of nuclei with Hoechst 33342 (Thermo Fisher Scientific, Waltham, MA, USA). Coverslips were attached to the microscope slides and imaged on confocal microscope (A1R Nikon) using excitation sources and filters appropriate for fluorescein.

\subsection{Real-Time Quantitative PCR (RT-qPCR)}

Total RNA from BMDMs, peritoneal macrophages, and RAW 264.7 cells was isolated using the SV Total RNA Isolation System (Promega, Madison, WI, USA) according to the manufacturer's protocol. Then, 800 ng (BMDMs, RAW 264.7 cells) or $200 \mathrm{ng}$ (peritoneal macrophages) of total DNAse-treated RNA was reverse transcribed using a Transcriptor First Strand cDNA Synthesis Kit (Roche Diagnostics, Basel, Switzerland). The amplified products were detected using SYBR Green I (Roche Diagnostics, Basel, Switzerland). Real-time quantitative PCR analysis was performed in a Light Cycler U96 (Roche Diagnostics, Basel, Switzerland) using gene-specific primer pairs (Table S1). Transcript levels were normalized relative to ribosomal protein L4 (Rpl4), ribosomal protein L19 (Rpl19), or hypoxanthine-guanine phosphoribosyltransferase (Hprt) expression levels. Control reference genes were selected using NomFinder software (NomFinder v0.953, Aarhus, Denmark, https: / / moma.dk/normfinder-software, accessed on 1 June 2014). Analysis of RT-qPCR results was based on $-\Delta \mathrm{Ct}$ (Ct of reference gene $-\mathrm{Ct}$ of test gene).

\subsection{Protein Extract Isolation and Western Blotting}

Cultured BMDMs and RAW 264.7 cells were washed with cold phosphate-buffered saline (PBS), scraped in $2 \mathrm{mM}$ EDTA/PBS buffer, and centrifuged $\left(500 \times g, 5 \mathrm{~min}, 4{ }^{\circ} \mathrm{C}\right)$. To obtain membrane and cytosolic fractions, cell pellets were suspended in lysis buffer (10 mM Tris $\mathrm{HCl}, \mathrm{pH} 7 ; 1 \mathrm{mM} \mathrm{MgCl} 2$ ) supplemented with a cocktail of protease inhibitors (Sigma-Aldrich, Burlington, MA, USA) and phenylmethanesulfonylfluoride (PMSF; SigmaAldrich, Burlington, MA, USA), left on ice for $30 \mathrm{~min}$ and homogenized by passing through a $255 / 8 \mathrm{G}$ needle. The homogenate was centrifuged $\left(8000 \times g, 5 \mathrm{~min}, 4{ }^{\circ} \mathrm{C}\right)$ and supernatant 
was ultracentrifuged $\left(80,000 \times g, 45 \mathrm{~min}, 4^{\circ} \mathrm{C}\right)$. The supernatants obtained after ultracentrifugation and enriched in cytosolic protein fraction were collected and stored at $-80{ }^{\circ} \mathrm{C}$. Final pellets (membrane extract) were resuspended in TNE buffer $(10 \mathrm{mM}$ Tris $\mathrm{HCl}, \mathrm{pH} 7$; $10 \mathrm{mM}$ EDTA; $0.1 \mathrm{M} \mathrm{NaCl}$ ) and stored at $-80{ }^{\circ} \mathrm{C}$ until use.

To obtain total cellular extracts, cell pellets were suspended in RIPA buffer (10 mM Tris pH8, $150 \mathrm{mM} \mathrm{NaCl}, 1 \mathrm{mM}$ EDTA, 1\% Igepal (NP40), 0.1\% SDS) supplemented with a protease inhibitor cocktail (Sigma-Aldrich, Burlington, MA, USA) and phenylmethanesulfonylfluoride (PMSF; Sigma-Aldrich, Burlington, MA, USA). The cells were left on ice for $30 \mathrm{~min}$ and then centrifuged $\left(6000 \times g, 15 \mathrm{~min}, 4^{\circ} \mathrm{C}\right)$. Protein concentrations were determined by Bradford assay (Bio-Rad, Hercules, CA, USA) and protein extracts were subjected to SDS-PAGE electrophoresis. Samples were not boiled before loading. Before membrane blocking with 5\% skim milk, transfer efficiency was confirmed by Ponceau-S staining. A list of primary and secondary antibodies used is given in Table S2. After incubation with primary antibody (overnight, $4^{\circ} \mathrm{C}$ ), blots were washed (TTBS buffer) and incubated with horseradish peroxidase-conjugated secondary antibodies at room temperature for $1 \mathrm{~h}$, followed by visualization with the enhanced luminescence kit (Thermo Fisher Scientific, Waltham, MA, USA).

\subsection{In-Cell Western Blot}

Primary peritoneal macrophages cultured in 24-well plates were fixed with ice-cold methanol at $-20{ }^{\circ} \mathrm{C}$ for 15 min, washed with PBS, and permeabilized with Triton $\mathrm{X}$ $100(0.1 \% / P B S)$ for $10 \mathrm{~min}$. Cells were blocked with Odyssey blocking buffer (LI-COR Bioscience, Lincoln, NE, USA) for $90 \mathrm{~min}$ at room temperature. Cells were incubated overnight at $4{ }^{\circ} \mathrm{C}$ with rabbit anti-mouse Fpn antibody $(1 / 500$; kind gift from $\mathrm{F}$. CanonneHergaux, INSERM, Toulouse, France) and mouse anti-mouse $\beta$-actin (1:500, Thermo Fisher Scientific, Waltham, MA, USA) in Odyssey blocking buffer. After being washed with $0.5 \%$ Tween-20/PBS, cells were incubated for $1 \mathrm{~h}$ at room temperature with donkey anti-rabbit LI-COR IRDye 680RD labeled secondary antibody (red, 1/500; LI-COR Bioscience, Lincoln, NE, USA) and donkey anti-mouse LI-COR IRDye 800CW labeled secondary antibody (green, 1/500; LI-COR Bioscience, Lincoln, NE, USA). Cells were washed 5 times with 0.5\% Tween-20/PBS and scanned by the Odyssey ${ }^{\circledR}$ Infrared Imaging System.

\subsection{Isolation of Lipid Raft Fractions}

Lipid rafts from RAW 264.7 cells were isolated as described previously [25,26]. Briefly, cells were washed with ice-cold PBS, scraped in $2 \mathrm{mM}$ EDTA/PBS, centrifuged $(500 \times g$, $\left.5 \mathrm{~min}, 4^{\circ} \mathrm{C}\right)$, and incubated on ice for $30 \mathrm{~min}$ in $600 \mu \mathrm{L}$ lysis buffer $(150 \mathrm{mM} \mathrm{NaCl} ; 25 \mathrm{mM}$ MES; 5 mM EDTA, pH 6.5; 1\% Triton X-100) supplemented with a cocktail of protease inhibitors (Sigma-Aldrich, Burlington, MA, USA) and phenylmethanesulfonylfluoride (PMSF; Sigma-Aldrich, Burlington, MA, USA). Samples were homogenized by passing through a $255 / 8 \mathrm{G}$ needle. The homogenate was centrifuged $\left(8000 \times g, 5 \mathrm{~min}, 4{ }^{\circ} \mathrm{C}\right)$ and supernatant was adjusted to a final concentration of $40 \%(w / v)$ iodixanol (OptiPrep ${ }^{\circledR}$, Sigma-Aldrich, Burlington, MA, USA), and the mixture was then layered under a 20-40\% discontinuous iodixanol gradient and centrifuged at $260,000 \times \mathrm{g}$ for $16 \mathrm{~h}$ at $4{ }^{\circ} \mathrm{C}$ using an SW 41 Ti Rotor (Beckman Coulter, Brea, CA, USA). Then, 11 fractions of $1 \mathrm{~mL}$ were collected from the top to the bottom of the gradient tube, and Western blot analysis of the fractions was performed. Lipid raft fractions were defined by the presence of a raft marker, flotilin 2 [27], while TfR1 was considered as a marker of non-lipid raft domains [28].

\subsection{Chemiluminescent RNA Electrophoretic Mobility Gel Shift Assay (EMSA)}

RNA-EMSA reaction was performed using a LightShift ${ }^{\circledR}$ Chemiluminescent RNA EMSA Kit (Thermo Fisher Scientific, Waltham, MA, USA) according to the manufacturer's instructions. Briefly, cytosolic extracts from control and $\mathrm{CuCl}_{2}$ - or LPS-treated BDMDs were obtained using NE-PER ${ }^{\mathrm{TM}}$ Nuclear and Cytoplasmic Extraction Reagents (Thermo Fisher Scientific, Waltham, MA, USA). Then, $20 \mu \mathrm{g}$ of cytosolic BMDM extract was mixed 
with REMSA Binding Buffer, glycerol, tRNA, and Biotin-IRE RNA probe and incubated for $30 \mathrm{~min}$ at room temperature. Samples were loaded on 5\% native polyacrylamide gel and subjected to protein electrophoresis in non-reducing and non-denaturing conditions in $0.5 \times$ TBE buffer $\left(100 \mathrm{~V}, 1 \mathrm{~h}, 4^{\circ} \mathrm{C}\right)$. Electrophoresed samples were transferred to a positively charged nylon membrane $\left(400 \mathrm{~mA}, 30 \mathrm{~min}, 4^{\circ} \mathrm{C}\right.$ ) (Thermo Fisher Scientific, Waltham, MA, USA). After transfer, crosslinking of RNA to membrane was performed using a UV lamp with $254 \mathrm{~nm}$ bulbs for $4 \mathrm{~min}$. Membrane was blocked with the manufacturer's blocking buffer and incubated with stabilized streptavidin-horseradish peroxidase conjugate for $15 \mathrm{~min}$ and washed extensively, and signal was developed using the chemiluminescence detection method. As a control, biotin-IRE control RNA and cytosolic liver extract +200 -fold molar excess of unlabeled IRE probe were used.

\subsection{Statistical Analysis}

Data are presented as mean values \pm standard deviation (SD). Statistical analysis was performed using Student's $t$-test (two groups considered) or one-way ANOVA (multiple groups) followed by Dunnett's post hoc multiple comparison test. Two-way ANOVA was used to assess statistical significance of the cytotoxic effect of $\mathrm{CuCl}_{2}$ treatment on BMDMs, followed by Tukey post hoc test. Statistical analysis was performed using GraphPad Prism 8.4.2 software (GraphPad, San Diego, CA, USA). ${ }^{*} p \leq 0.05,{ }^{* *} p \leq 0.01,{ }^{* * *} p \leq 0.001$, and $* * * * p \leq 0.0001$ were considered significant.

\section{Results}

3.1. Exposure of Bone-Marrow-Derived Macrophages to $\mathrm{CuCl}_{2}$ Results in Intracellular Copper Loading without Significant ROS Production

The toxicity of copper is usually associated with its redox activity. In order to determine a nontoxic dose of $\mathrm{CuCl}_{2}$ and the optimal timing of exposure of bone-marrow-derived macrophages (BMDMs) to $\mathrm{Cu}$ ions, cell viability and cytotoxicity assays were performed after the incubation of BMDMs with increasing concentrations of $\mathrm{CuCl}_{2}$. We observed that only a high $\mathrm{CuCl}_{2}$ concentration $(500 \mu \mathrm{M})$ elicited strong cytotoxicity compared to lower doses, regardless of the duration of exposure (Figure 1a). Overnight $(24 \mathrm{~h})$ incubation of BMDMs with $150 \mu \mathrm{M} \mathrm{CuCl}_{2}$ significantly increased the cellular copper content (as measured by ICP-MS), indicating effective copper transport into the cells (Figure 1b). The intracellular reactive oxygen species (ROS) level was measured by the intensity of fluorescence of $\mathrm{H}_{2}$ DCFDA-treated cells. The data demonstrate that despite increased intracellular $\mathrm{Cu}$ loading, BMDMs treated with $150 \mu \mathrm{M} \mathrm{CuCl}_{2}$ did not show increased ROS production compared to cells exposed to cytotoxic $500 \mu \mathrm{M} \mathrm{CuCl}_{2}$ (Figure 1c).

\subsection{Copper Loading Upregulates Fpn mRNA Abundance in BMDMs in an Nrf2-Dependent Manner}

Previous studies have shown that copper increases Fpn mRNA levels in the J774 macrophage cell line, but the detailed mechanism of this regulation has not been defined [10]. Here, we report that in primary BMDMs, Fpn mRNA expression increased significantly after exposure to $\mathrm{CuCl}_{2}$ in a dose- and time-dependent manner (Figure 2a,b). To determine whether copper loading affects the transcription rate and Fpn mRNA stability, BMDMs were pretreated with $150 \mu \mathrm{M} \mathrm{CuCl}_{2}$ for $16 \mathrm{~h}$ and exposed for 2 and $8 \mathrm{~h}$ to an RNA synthesis inhibitor, $\alpha$-amanitin $(2 \mu \mathrm{g} / \mathrm{mL})$. As shown in Figure $2 \mathrm{c}, \alpha$-amanitin blocked copper-induced Fpn mRNA expression but significantly increased its stability, as demonstrated by higher mRNA levels after $8 \mathrm{~h}$ incubation with the inhibitor. 


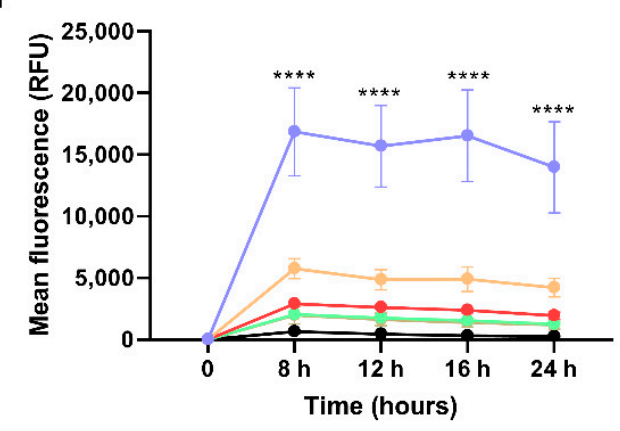

b

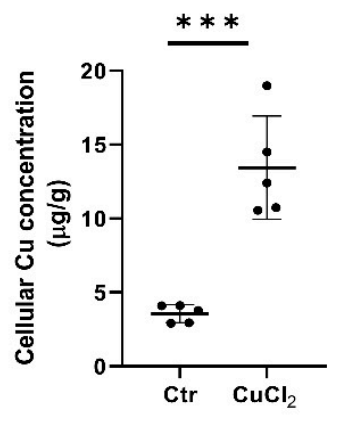

C

$\rightarrow 500 \mu \mathrm{M}$

$-300 \mu \mathrm{M}$

$\rightarrow 250 \mu \mathrm{M}$

- $150 \mu \mathrm{M}$

- $50 \mu \mathrm{M}$

$\rightarrow 25 \mu \mathrm{M}$

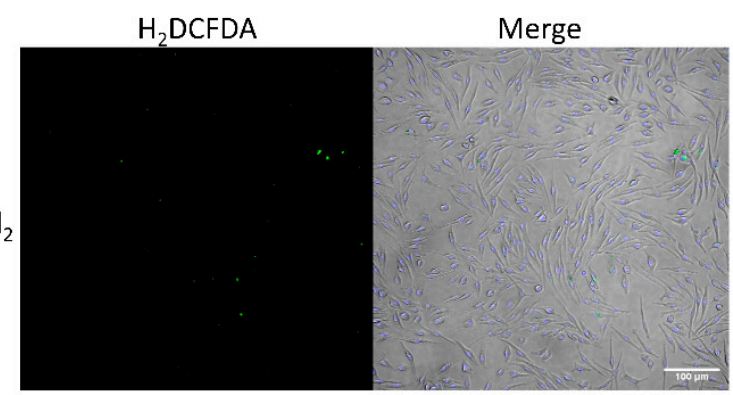

$150 \mu \mathrm{M} \mathrm{CuCl}_{2}$
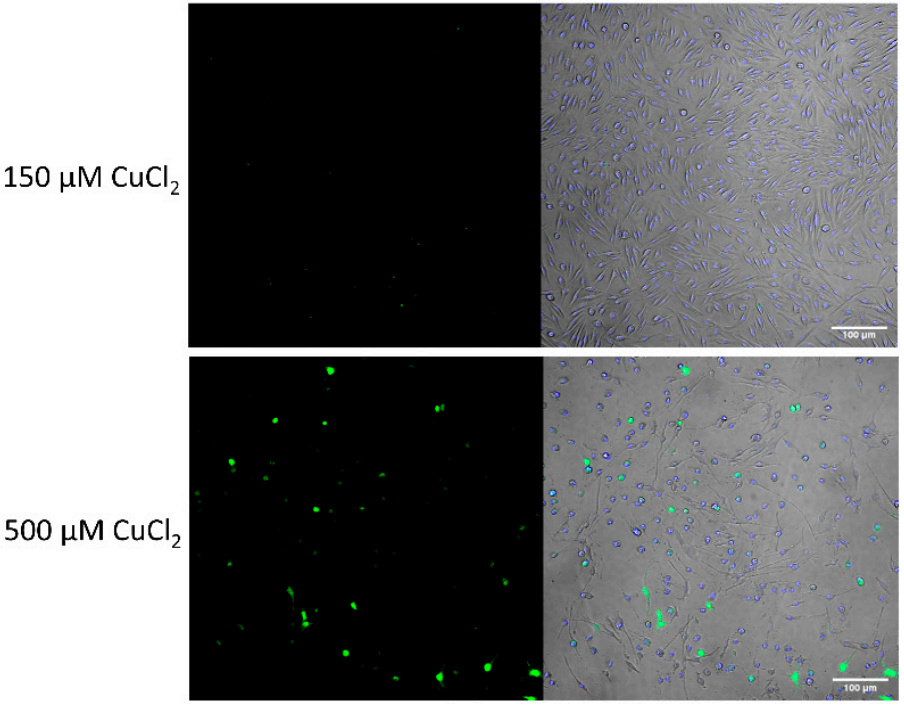

Figure 1. $\mathrm{CuCl}_{2}$ toxicity and ROS production in BMDMs. (a) Cytotoxic effect of $\mathrm{CuCl}_{2}$ treatment on BMDMs was measured in time $(8-24 \mathrm{~h})$ and dose $(25-500 \mu \mathrm{M})$-dependent manner. Fluorescence signal (RFU) produced by the dye binding to the dead-cell DNA is proportional to cytotoxicity. Ex: $485 \mathrm{~nm}, \mathrm{Em}$ : 520nm. Data were normalized to values obtained for non-treated control cells. Results are presented as mean $\pm \mathrm{SD}$, ${ }^{* * * *} p<0.0001$. (b) Cellular copper concentration in BMDMs was determined by ICP-MS after $16 \mathrm{~h}$ incubation with $150 \mu \mathrm{M} \mathrm{CuCl}_{2}$. Data are presented as mean $\pm \mathrm{SD}$, ${ }^{* * *} p<0.001$. (c) ROS production: confocal images of BMDMs treated with 50,150, and $500 \mu \mathrm{M} \mathrm{CuCl}_{2}$ loaded with $5 \mu \mathrm{M}$ of ROS probe $\mathrm{H}_{2}$ DCFDA. Hoechst was used as nucleus stain. Scale bar: $100 \mu \mathrm{m}$.

In separate studies, heme was shown to be a strong positive transcriptional regulator of Fpn mRNA expression, which allows the binding of Nrf2 to the ARE sequence within the Fpn promoter [5].

The incubation of BMDMs with $150 \mu \mathrm{M} \mathrm{CuCl}_{2}$ for $16 \mathrm{~h}$ led to an increased expression of Fpn and Nqo1, the previously described Nrf2 target gene (Figure 2d,e) [29]. Moreover, as shown in Figure $2 \mathrm{f}$, the basal level of Fpn expression strictly depends on Nrf2. Interestingly, the $\mathrm{CuCl}_{2}$ transcriptional effect was not observed in BMDMs derived from Nrf2 knockout mice (Figure 2g-i), which clearly indicates the role of Nrf2 in copper-dependent transcriptional Fpn upregulation. 
a

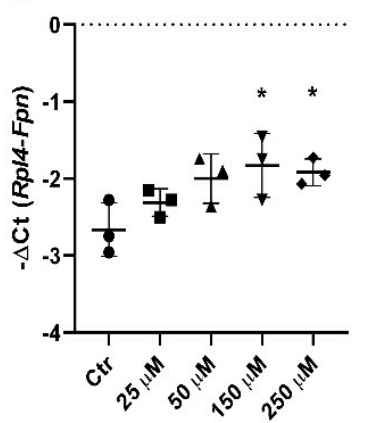

b

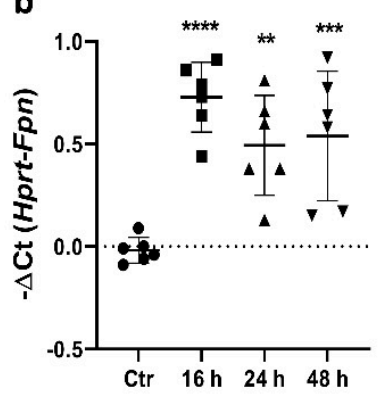

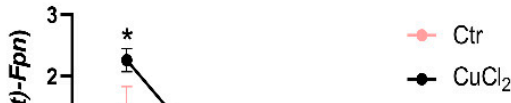

d

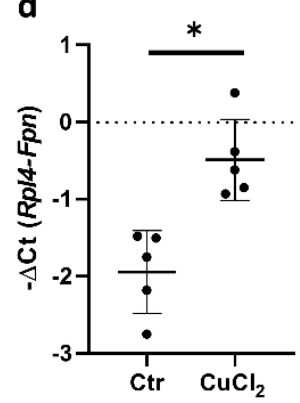

e

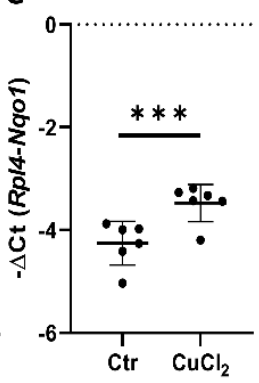

\begin{abstract}
f
\end{abstract}

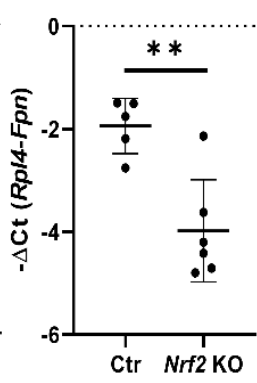

g

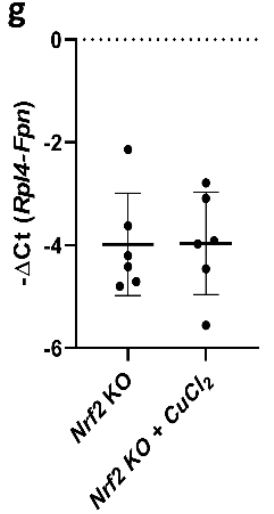

h

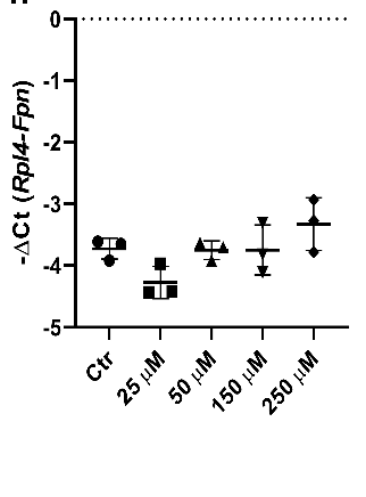

i

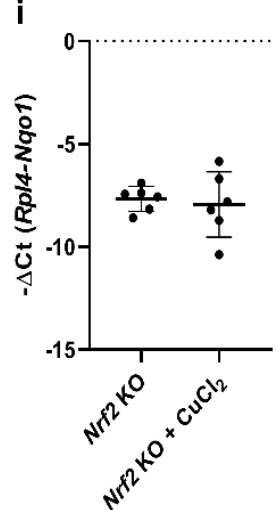

Figure 2. Copper loading affects Fpn transcription in BMDMs. (a) qPCR analysis of Fpn mRNA expression in BMDMs after $16 \mathrm{~h}$ exposure to various $\mathrm{CuCl}_{2}$ concentrations. Data represent mean $\pm \mathrm{SD},{ }^{*} p<0.05$. (b) $\mathrm{qPCR}$ analysis of Fpn mRNA expression in BMDMs after exposure to $150 \mu \mathrm{M} \mathrm{CuCl}_{2}$ for 16,24 , and $48 \mathrm{~h}$. Data represent mean $\pm \mathrm{SD},{ }^{* *} p<0.01$, ${ }^{* * *} p<0.001,{ }^{* * * *} p<0.0001$. (c) qPCR analysis of Fpn mRNA expression in BMDMs after 16 h exposure to $150 \mu \mathrm{MCuCl}_{2}$ followed by 2 and $8 \mathrm{~h}$ incubation with $2 \mu \mathrm{g} / \mathrm{mL} \alpha$-amanitin. Data were normalized to expression level of two reference genes, Rpl19 and Hprt. Results presented as mean $\pm \mathrm{SD},{ }^{*} p<0.05,{ }^{* *} p<0.01$. (d,e) qPCR analysis of Fpn and Nqo1 mRNA expression in BMDMs after $16 \mathrm{~h}$ exposure to $150 \mu \mathrm{MCuCl}_{2}$. Data represent mean $\pm \mathrm{SD},{ }^{*} p<0.05,{ }^{* * *} p<0.001$. (f) $\mathrm{qPCR}$ analysis of Fpn mRNA expression in BMDMs derived from wild-type and Nrf2 knockout mice after $16 \mathrm{~h}$ exposure to $150 \mu \mathrm{M}$ $\mathrm{CuCl}_{2}$. Data represent mean $\pm \mathrm{SD}$, ${ }^{* *} p<0.01$. (g-i) qPCR analysis of Fpn and Nqo1 mRNA expression in BMDMs derived from Nrf2 knockout mice after $16 \mathrm{~h}$ exposure to $150 \mu \mathrm{M} \mathrm{CuCl}_{2}$. Data represent mean $\pm \mathrm{SD}$. Graph in (h) reflects Fpn mRNA expression level in $\mathrm{Nrf2}$ knockout BMDMs after $16 \mathrm{~h}$ exposure to various $\mathrm{CuCl}_{2}$ concentrations.

\subsection{Copper Loading Counterbalances LPS-Induced Suppression of Fpn mRNA Expression in Macrophages}

It has been shown previously that LPS treatment decreases Fpn expression, and pharmacological activators of Nrf2 can counteract the LPS-induced suppression of Fpn mRNA $[19,30]$. Our results, as well as studies on BMDMs described by Achard and co-workers [22], indicate that LPS treatment significantly increases the expression of genes responsible for copper uptake (Ctr1) and intracellular trafficking (Atp7a) in BMDMs (Figure 3a,b). Interestingly, while LPS stimulation leads to a profound decrease in Fpn expression, concomitant $\mathrm{CuCl}_{2}$ treatment restores this declined expression to the level observed in control BMDMs (Figure 3c). Moreover, the same effect was observed in RAW macrophages (Figure 3d). These data indicate that the copper-dependent transcriptional upregulation of Fpn mRNA expression is effective enough to counteract LPS-mediated downregulation. 
a
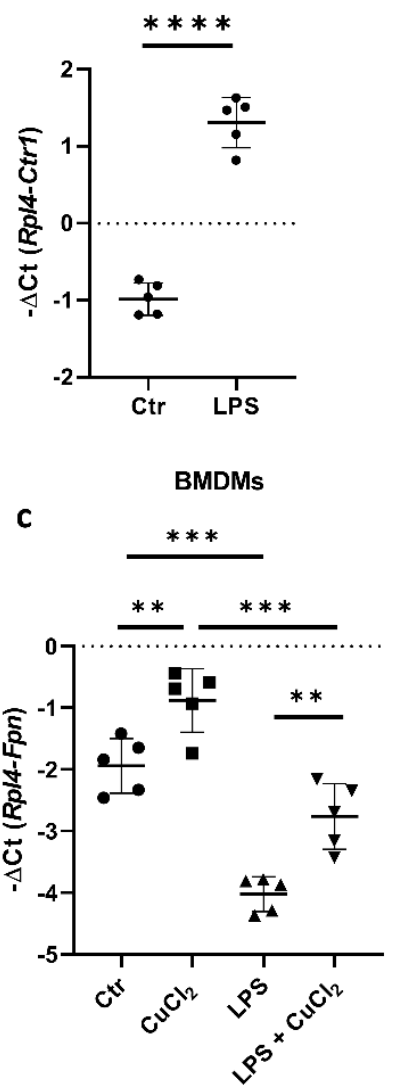

b
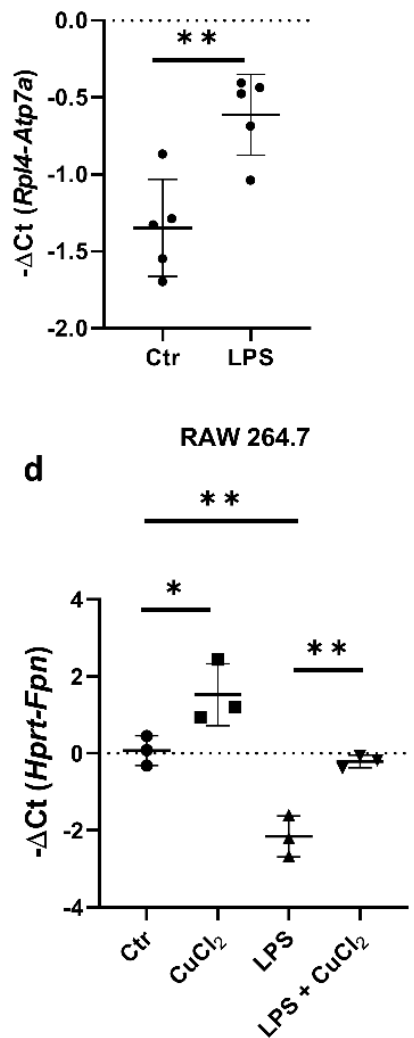

Figure 3. Copper loading counterweights LPS-induced suppression of Fpn mRNA. (a,b) qPCR analysis of Ctr1 and Atp7a mRNA expression in BMDMs incubated with $100 \mathrm{ng} / \mathrm{mL}$ lipopolysaccharide (LPS) for $16 \mathrm{~h}$. Data represent mean $\pm \mathrm{SD}$, ${ }^{* *} p<0.01,{ }^{* * * *} p<0.0001$. qPCR analysis of Fpn mRNA expression in (c) BMDMs and (d) RAW 264.7 macrophages treated with 100 or $200 \mathrm{ng} / \mathrm{mL}$ LPS, respectively, in the absence or presence of $150 \mu \mathrm{M} \mathrm{CuCl}_{2}$ for $16 \mathrm{~h}$. Data represent mean $\pm \mathrm{SD}$, ${ }^{*} p<0.05,{ }^{* *} p<0.01,{ }^{* * *} p<0.001$.

\subsection{Possible Mechanisms of Copper-Dependent Decrease in Fpn Protein Level}

In order to confirm that the upregulation of Fpn mRNA expression is reflected in higher protein levels in BMDMs, Western blot analysis using subcellular membrane fraction was performed. Surprisingly, the exposure of BMDMs to $150 \mu \mathrm{M} \mathrm{CuCl}_{2}$ for $16 \mathrm{~h}$ did not significantly affect $\mathrm{Fpn}$ protein levels (Figure $4 \mathrm{a}$, upper panel). Moreover, longer incubation of $\mathrm{BMDMs}_{\text {with }} \mathrm{CuCl}_{2}(24-48 \mathrm{~h}$ ) led to a marked decrease in Fpn abundance on macrophage membranes (Figure $4 \mathrm{a}$, bottom panel). To assess whether the reduced level of this iron exporter could affect cellular iron homeostasis, the level of ferritin, an iron storage protein, was evaluated. Cytosolic ferritin is composed of 24 subunits of two types, light (L-Ft) and heavy $(\mathrm{H}-\mathrm{Ft})$, depending on their relative molecular weights. The $\mathrm{H}$ chain exhibits ferroxidase activity and is especially important for macrophages [31,32]. As shown in Figure $4 \mathrm{~b}, \mathrm{c}$, Fpn downregulation did not significantly change the level of either L- or $\mathrm{H}-\mathrm{Ft}$ subunits. Moreover, $\mathrm{CuCl}_{2}$ treatment had no influence on the expression of transferrin receptor-1 (TfR1) mRNA (Figure 4d). The TfR1 mRNA level reflects intracellular iron content, as its abundance is inversely correlated with cellular iron status by means of post-transcriptional regulation through Iron Regulatory Proteins (IRPs) that bind ironresponsive element (IRE) sequences located within the $3^{\prime}$ UTR of TfR1 mRNA $[33,34]$. 

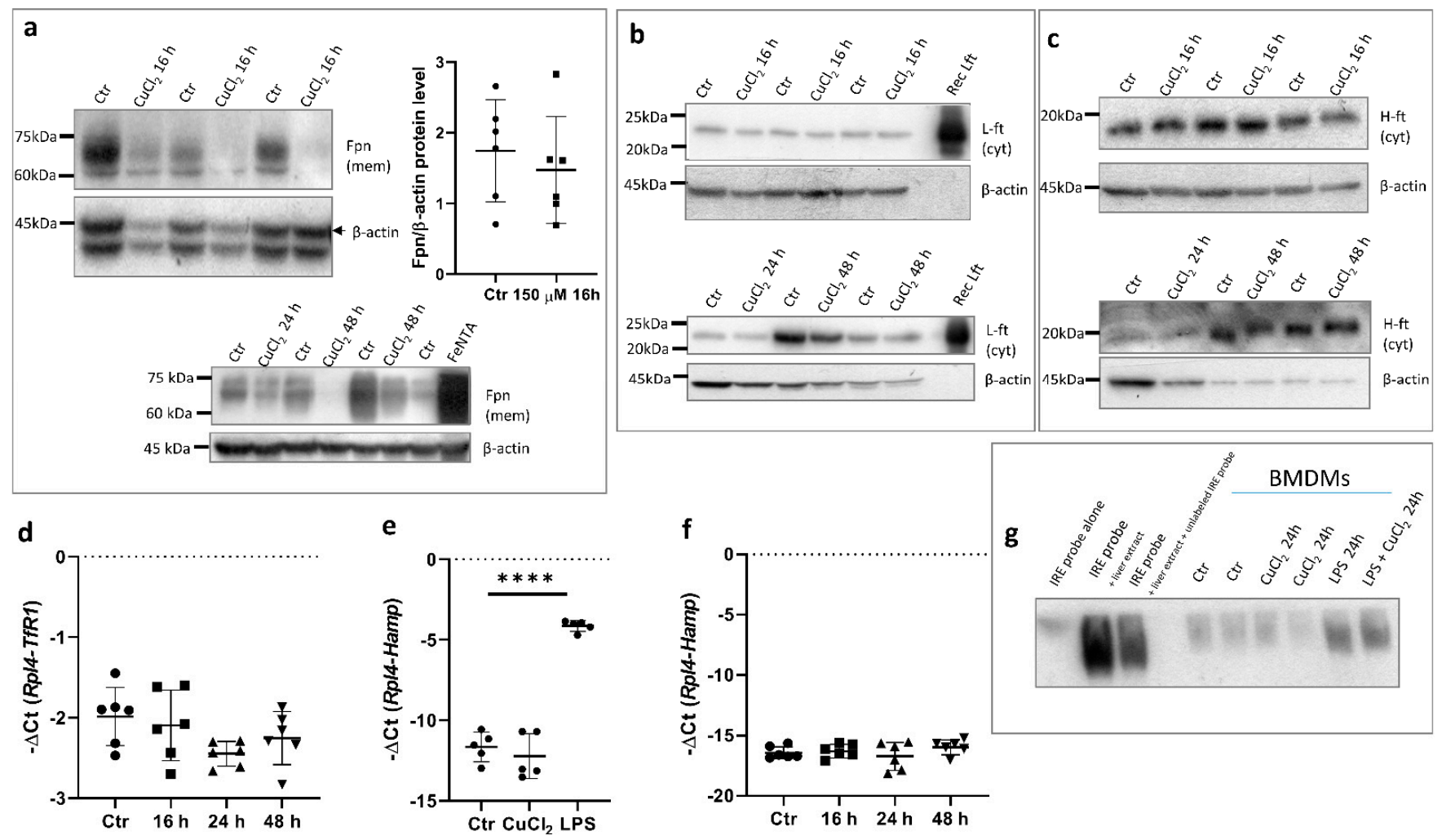

Figure 4. Copper loading decreases Fpn protein levels in hepcidin- and IRE-independent manner. (a) Upper panel: Western blot analysis of Fpn protein level in membrane fraction of control cells and BMDMs treated with $150 \mu \mathrm{M} \mathrm{CuCl}_{2}$ for $16 \mathrm{~h}$. Graph illustrates densitometric analysis of Fpn protein level normalized to $\beta$-actin level from 6 independent experiments. Bottom panel: Western blot analysis of Fpn protein level in membrane fraction of control cells and BMDMs treated with $150 \mu \mathrm{M} \mathrm{CuCl}_{2}$ for 24 and $48 \mathrm{~h}$. BMDMs stimulated with $150 \mu \mathrm{M}$ FeNTA were used as positive controls to check specificity of antibody. (b) Western blot analysis of L-ferritin protein level in cytosolic fraction of control cells and $150 \mu \mathrm{M} \mathrm{CuCl}_{2}$-treated BMDMs. Recombinant mouse ferritin light chain (Rec L-Ft) was used as positive control. (c) Western blot analysis of $\mathrm{H}$-ferritin protein levels in cytosolic fraction of control and $150 \mu \mathrm{M} \mathrm{CuCl}_{2}$-treated BMDMs. (d) qPCR analysis of TfR1 mRNA expression in BMDMs incubated with $150 \mu \mathrm{M} \mathrm{CuCl}_{2}$ for 16, 24, and $48 \mathrm{~h}$. Data represent mean $\pm \mathrm{SD}$. (e) qPCR analysis of Hamp expression in BMDMs incubated with $150 \mu \mathrm{M} \mathrm{CuCl}_{2}$ or $100 \mathrm{ng} / \mathrm{mL}$ lipopolysaccharide (LPS) for $16 \mathrm{~h}$. Data represent mean $\pm \mathrm{SD}$, ${ }^{* * * *} p<0.0001$. (f) qPCR analysis of Hamp mRNA expression in BMDMs incubated with $150 \mu \mathrm{M}$ $\mathrm{CuCl}_{2}$ for 16,24 , and $48 \mathrm{~h}$. Data represent mean $\pm \mathrm{SD}$. (g) RNA-EMSA was performed to assess IRE-IRP binding activity in BMDMs treated with $150 \mu \mathrm{M} \mathrm{CuCl}_{2}$ or $200 \mathrm{ng} / \mathrm{mL}$ LPS for $24 \mathrm{~h}$. Cytosolic extract (20 $\left.\mu \mathrm{g}\right)$ from BDMDs was incubated with biotinylated IRE probe, and RNA-protein complexes were separated on non-denaturing polyacrylamide gel. Biotin-IRE control RNA, biotin-IRE control RNA + cytosolic extract from liver $(5 \mu \mathrm{g})$, and biotin-IRE control RNA + cytosolic extract from liver $(5 \mu \mathrm{g})+200$-fold molar excess of unlabeled IRE RNA were used as positive control reaction.

Hepcidin is the main regulator of iron homeostasis. Its binding to ferroportin leads to the rapid internalization and degradation of this protein [4]. Hepcidin is mainly produced by hepatocytes, but its expression increases in pro-inflammatory macrophages infected with intracellular pathogens [35]. Indeed, the exposure of BMDMs to $100 \mathrm{ng} / \mathrm{mL}$ LPS significantly increased hepcidin mRNA levels, whereas treatment with $150 \mu \mathrm{M} \mathrm{CuCl}_{2}$ did not change the expression of the Hamp gene (Figure 4e,f). This allows us to conclude that the hepcidin-ferroportin interaction is not responsible for the decrease in the Fpn protein level after prolonged $\mathrm{CuCl}_{2}$ treatment.

The translational regulation of Fpn occurs via the binding of Iron Regulatory Proteins (IRPs) to iron responsive element (IRE) sequences localized within the $5^{\prime}$ UTR of the Fpn transcript $[3,36]$. In order to determine if $\mathrm{CuCl}_{2}$ treatment influences IRE-IRP binding activity, we performed an electrophoretic mobility shift assay (EMSA) in BMDM cytosolic extracts. As shown in Figure $4 \mathrm{~g}$, we did not observe significant differences in IRP-IRE 
binding activity between control and $\mathrm{CuCl}_{2}$-treated cells. Moreover, LPS treatment significantly increased IRP-IRE binding activity, which was previously shown in the J774 macrophage cell line [37]. Similarly, the exposure of cells to $\mathrm{CuCl}_{2}$ did not influence this activity, which suggests that the mechanism responsible for the decreased Fpn protein level in copper-loaded BMDMs does not involve translational repression through the IRP/IRE system.

Lysosomal proteolytic breakdown of Fpn is thought to be responsible for its biological degradation [4]. To further investigate the mechanism responsible for membrane-bound Fpn protein $\mathrm{CuCl}_{2}$-mediated downregulation, we treated BMDMs with $100 \mu \mathrm{M}$ chloroquine (Chlq), a known inhibitor of lysosome function. Surprisingly, Chlq treatment led to a significant decrease in Fpn abundance in the membrane fraction of BMDMs (Figure 5a). Moreover, $\mathrm{Chlq}$ and concomitant $\mathrm{CuCl}_{2}$ treatment affected cellular ferritin protein levels, leading to increased abundance of the $\mathrm{H}-\mathrm{Ft}$ subunit (Figure $5 \mathrm{~b}$, upper panel), accompanied by a persistent $\mathrm{Fpn}$ decline (Figure $5 \mathrm{~b}$, bottom panel). We checked whether $\mathrm{CuCl}_{2}$ treatment affects the expression of genes involved in the processes of ubiquitination (Usp14, Ubc), multivesicular bodies (MVBs; specialized subset of endosomes that contain membranebound intraluminal vesicles) (Lip5, Chmp5), and proteasome formation (Psma1, Psmc4), and did not observe statistical differences (Figure $5 c-e$ ).
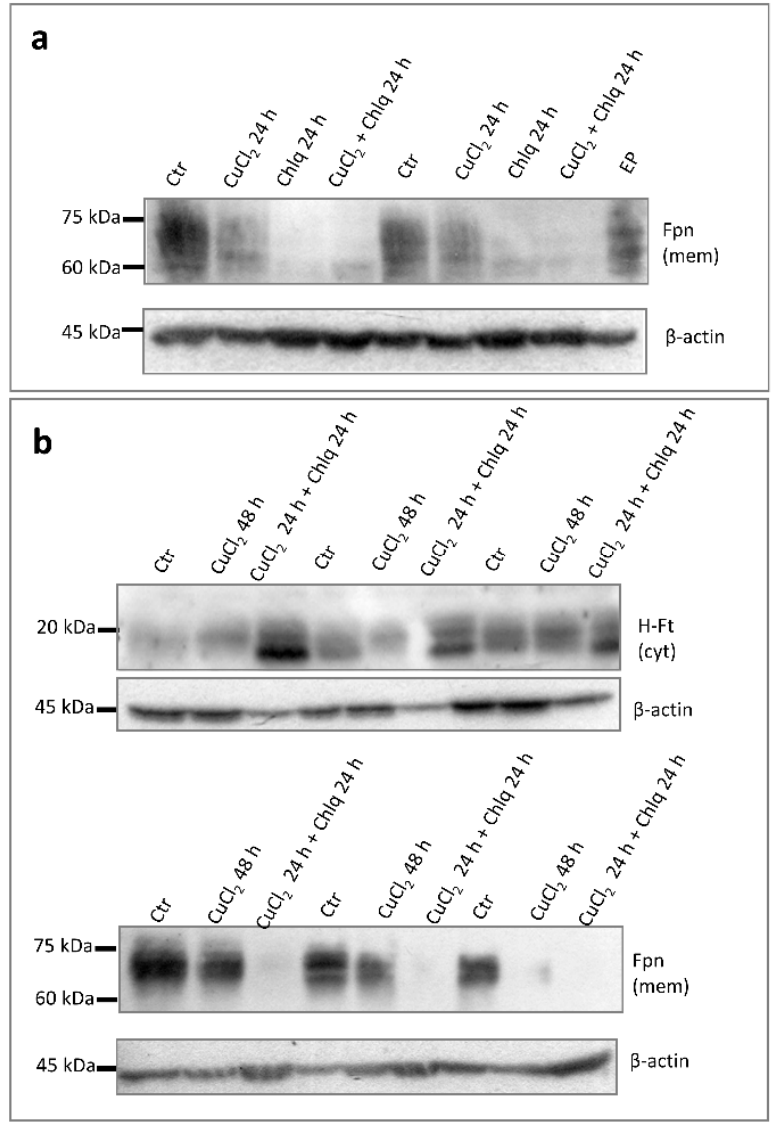
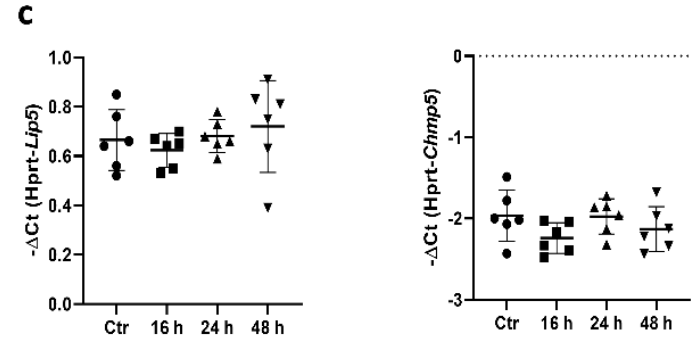

d
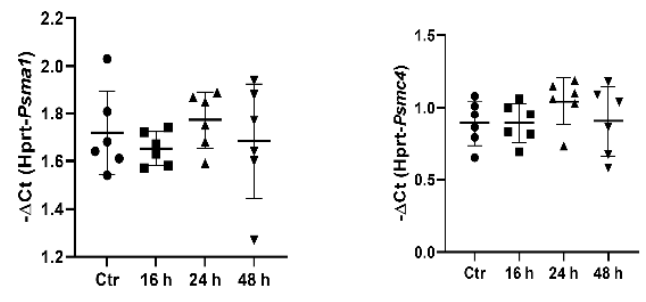

e

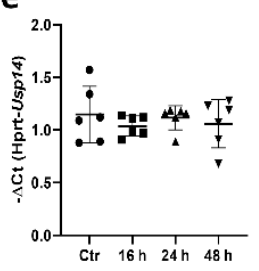

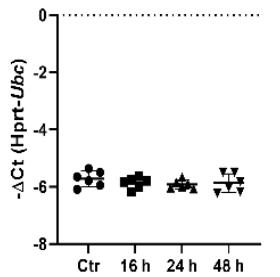

Figure 5. Impact of copper loading on mechanisms controlling Fpn protein degradation in BMDMs. (a) Western blot analysis of Fpn protein level in membrane fraction of BMDMs treated with $150 \mu \mathrm{M} \mathrm{CuCl}_{2}, 100 \mu \mathrm{M}$ chloroquine, or combination of both for $24 \mathrm{~h}$. Extract derived from BMDMs after $6 \mathrm{~h}$ of erythrophagocytosis (EP) was used as a positive control. (b) Western blot analysis of $\mathrm{H}$-ferritin protein level in cytosolic fraction (upper panel) and Fpn protein level in membrane fraction (bottom panel) of BMDMs treated with $150 \mu \mathrm{M} \mathrm{CuCl}_{2}$ for $48 \mathrm{~h}$ or pretreated with $150 \mu \mathrm{M} \mathrm{CuCl}_{2}$ for $24 \mathrm{~h}$ followed by $100 \mu \mathrm{M}$ chloroquine stimulation for remaining $24 \mathrm{~h}$. (c-e) qPCR analysis of Lip5, Chmp5, Psma1, Psmc4, Usp14, and Ubc mRNA expression in BMDMs incubated with $150 \mu \mathrm{M} \mathrm{CuCl}_{2}$ for 16, 24, and $48 \mathrm{~h}$. Data represent mean \pm SD. 


\section{5. $\mathrm{CuCl}_{2}$ Treatment Affects Fpn Expression in Different Subset of Macrophages}

We further investigated whether, similar to BMDMs, exposure of the RAW 264.7 monocyte/macrophage-like cell line and primary peritoneal macrophages to $\mathrm{CuCl}_{2}$ would affect Fpn expression. As shown in Figure $6 \mathrm{a}, \mathrm{CuCl}_{2}$ treatment slightly increased Fpn mRNA expression $(p=0.05)$ in peritoneal macrophages, but in contrast to BMDMs, the Fpn protein level was not changed after $\mathrm{CuCl}_{2}$ exposure, as evaluated by In-Cell Western blot quantification (Figure 6b). This indicates that factors specific to the macrophage population can influence Fpn regulation in response to copper loading.

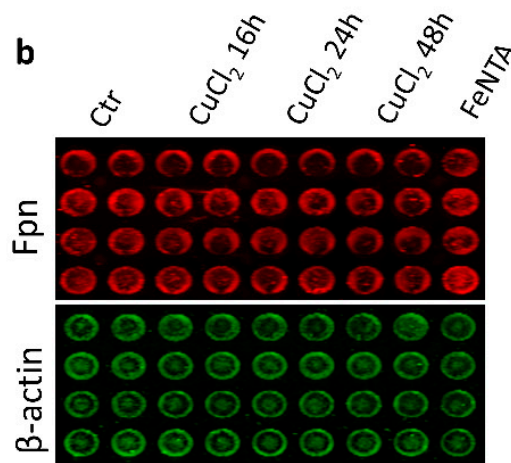

a

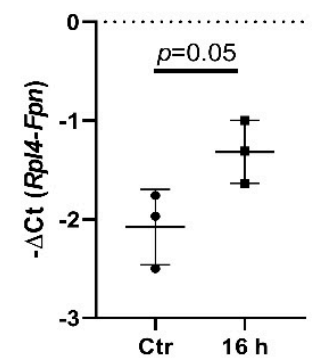

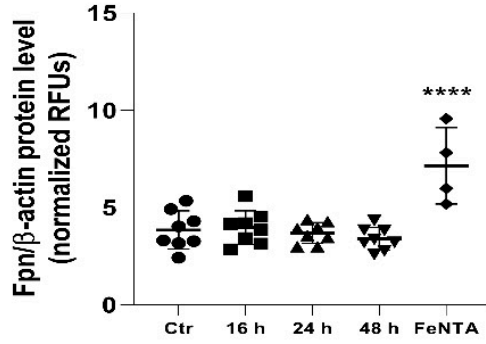

Figure 6. $\mathrm{CuCl}_{2}$ treatment does not affect Fpn mRNA and protein levels in primary peritoneal macrophages. (a) qPCR analysis of Fpn mRNA expression in primary peritoneal macrophages incubated with $150 \mu \mathrm{M} \mathrm{CuCl}_{2}$ for $16 \mathrm{~h}$. Data represent mean \pm SD. (b) In-Cell Western blot detection (left panel) and quantification (histogram) of Fpn expression in peritoneal macrophages treated with $150 \mu \mathrm{M} \mathrm{CuCl}_{2}$ for 16,24 , and $48 \mathrm{~h}$. Cells treated with Fe-NTA $(200 \mu \mathrm{M})$ were used as positive control. Fpn intensity signal was normalized to $\beta$-actin level. Data on histogram represent mean $\pm \mathrm{SD},{ }^{* * * *} p<0.0001$.

Interestingly, treatment with $150 \mu \mathrm{M} \mathrm{CuCl}_{2}$ led to a significant time-dependent increase in Fpn expression in RAW 264.7 macrophages, on both the mRNA and protein level (Figure 7a,b). Interestingly, the upregulation of Fpn mRNA was already significant after $6 \mathrm{~h}$ exposure to $150 \mu \mathrm{M} \mathrm{CuCl}_{2}$ (data not shown), which was not the case for BMDMs. Increased Fpn protein abundance was observed in both total cell extract and membrane subcellular fractions (Figure 7b). It has been previously described that in macrophages, ferroportin is mostly detected in detergent-resistant membranes containing lipid raft markers, and iron overload strongly increases the presence of ferroportin in the lightest raft fraction [25]. Here, we investigated whether copper loading leads to similar Fpn protein distribution within membrane fractions as observed after iron treatment. Raft-enriched fractions from RAW macrophages were obtained by Optiprep gradient density ultracentrifugation, followed by Western blot analysis of membrane fractions. As shown in Figure 7c, in RAW macrophages, after iron treatment, Fpn was mostly detected in lighter lipid raft-enriched membrane fractions. Interestingly, exposure to $\mathrm{CuCl}_{2}$ led to Fpn localization within lipid raft and non-lipid raft-enriched fractions, which could reflect the distinct regulation of Fpn present on the cellular membrane. 
a

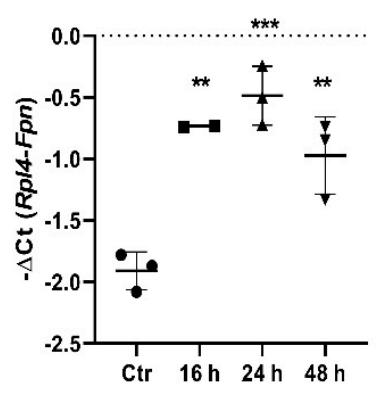

C

$200 \mu \mathrm{M}$ FeNTA $24 \mathrm{~h}$

$\begin{array}{lllllllll}1 & 2 & 4 & 5 & 7 & 8 & 9 & 10 & 11\end{array}$

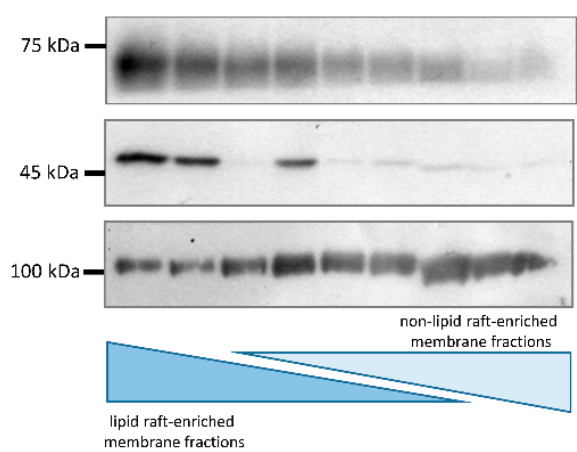

b

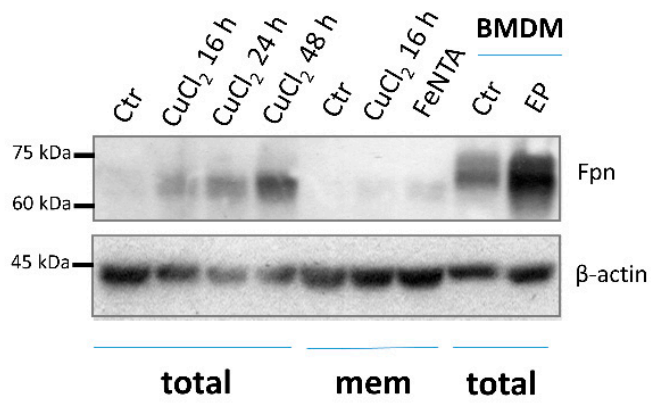

$150 \mu \mathrm{M} \mathrm{CuCl}_{2} 48 \mathrm{~h}$

$\begin{array}{lllllllll}1 & 2 & 4 & 5 & 7 & 8 & 9 & 10 & 11\end{array}$

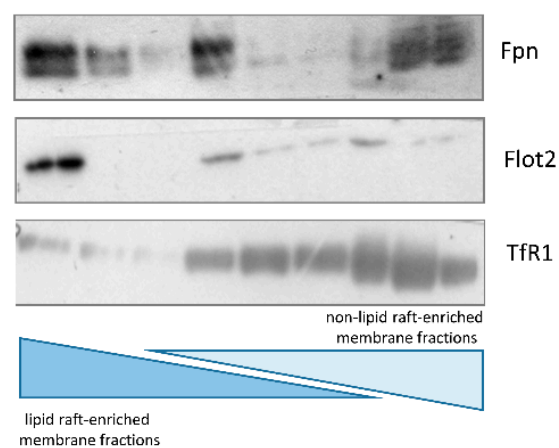

Figure 7. Copper loading increases Fpn mRNA level. (a) qPCR analysis of Fpn expression in RAW 264.7 cells incubated with $150 \mu \mathrm{MCuCl}_{2}$ for 16,24 , and $48 \mathrm{~h}$. Data represent mean $\pm \mathrm{SD}$, ** $p<0.01$, *** $p<0.001$. (b) Western blot analysis of Fpn protein level in total extract and membrane fraction of control and $150 \mu \mathrm{M} \mathrm{CuCl}_{2}$-treated RAW 264.7 cells. Extract derived from BMDMs after $6 \mathrm{~h}$ of erythrophagocytosis (EP) was used as positive. (c) Western blot detection of Fpn and flotilin 2 (Flot2; raft marker) in lipid raft and non-raft-enriched (TfR1) membrane fractions of Fe-NTA $(200 \mu \mathrm{M})$ and $\mathrm{CuCl}_{2}(150 \mu \mathrm{M})$ treated RAW 264.7 macrophages. Numbers indicate subsequent fractions collected after discontinuous iodixanol density gradient ultracentrifugation.

\section{Discussion}

Reticuloendothelial macrophages (located in the liver, spleen, and bone marrow) play a crucial role in systemic iron turnover [38]. These cells express a set of proteins strictly connected to iron metabolism, including membrane-bound ferroportin (Fpn), the only known iron exporter. Due to its critical function in iron metabolism, Fpn expression is tightly regulated at both the cellular and systemic level. Most of the regulatory mechanism involves iron-related molecules [1]. It has been proven that other transition metals, such as cadmium, cobalt, copper, manganese, and zinc, are able to induce Fpn transcription [9], but the physiological relevance of such regulation remains largely unknown. Previous studies provided clear evidence of Fpn-mediated cellular efflux of iron, cobalt, and zinc, but not cadmium and copper [39]. Interestingly, it seems that significant differences exist regarding the mechanisms of transcriptional regulation of the Fpn gene by exposure to various transition metals. Metal transcription factor-1 (MTF-1) mediates the response to both metal excess and deprivation and is responsible for cellular protection against oxidative stress [40]. Zinc and cadmium induce Fpn transcription through the action of MTF-1, which is not the case for copper [9].

Interactions between copper and iron metabolism have been known for years and are mainly connected with processes of absorption, storage, and redistribution of those metals [11]. It is known that copper accumulates in the liver during iron deficiency and iron accumulates in the liver during copper deficiency [41,42]. To date, the molecular basis 
of those interplays still remains unknown. Here, we demonstrate that copper loading significantly increases the transcription of the Fpn gene, in both primary bone-marrowderived macrophages (BMDMs) and the macrophage-like RAW 264.7 cell line. Importantly, this effect was not observed in BMDMs derived from Nrf2 knockout mice, which indicates the role of this transcription factor in the process of $\mathrm{Cu}$-dependent upregulation of $\mathrm{Fpn}$ transcription. Previously, the role of Nrf2 in heme-dependent ferroportin transcriptional induction via its binding to an antioxidant response element (ARE) sequence in the promoter of the Fpn gene was proven [5]. Herein, we are able to show that basal Fpn mRNA expression is also strictly dependent on Nrf2.

The ability of $\mathrm{Cu}$ to potentiate the activation of the Nrf2/ARE pathway in macrophages could be especially valuable in the context of the anti-inflammatory role of Nrf2, which contributes to the recruitment of inflammatory cells and regulation of gene expression [43]. Studies on copper-deficient animals clearly indicate the role of copper in immunomodulation [44]. Achard and co-workers showed that LPS and Salmonella infection increase the expression of genes responsible for copper uptake (Ctr1) and cellular copper redistribution $($ Atp 7a) in macrophages [22]. Moreover, macrophage-mediated bacterial killing was shown to be strictly dependent on the presence of the Atp7a copper transporter on the phagosomal membrane [23], which could pump $\mathrm{Cu}$ into the lumen. Here, we also observed a significant induction of $\mathrm{Ctr} 1$ and Atp7a expression in BMDMs, which confirms the ability of macrophages to alter their copper homeostasis under inflammatory conditions. On the other hand, iron handling within infected macrophages fits into the concept of "nutritional immunity", where necessary elements such as iron are sequestered within cells (mainly macrophages) to reduce its availability to pathogens [45]. One of the mechanisms responsible for controlling iron accessibility during inflammation is the transcriptional repression of Fpn expression. This effect was observed in both in vivo and in vitro studies, where LPS treatment significantly decreased Fpn mRNA in macrophages [18,30,46,47].

When the iron sequestration process is prolonged, it can lead to hypoferremia and anemia of inflammation [16]; therefore, macrophages should release iron during the resolution phase of inflammation. Here, we observed that in both primary BMDMs and RAW 264.7 macrophages, LPS treatment significantly decreased Fpn mRNA levels, but concomitant $\mathrm{CuCl}_{2}$ stimulation was able to counteract the transcriptional suppression of $\mathrm{Fpn}$ and restore its expression to the level observed in the control group. It was previously reported that diethyl maleate and sulforaphane (both Nrf2 activators) are able to rescue Fpn expression after LPS treatment, but the mechanism remains unknown [19]. The increased expression of genes responsible for copper uptake and trafficking in macrophages after LPS treatment suggests that copper loading could enhance bacterial killing efficiency by generating reactive oxygen species (ROS) and influence the expression of Fpn, leading to scarce iron for intracellular pathogens via cytosolic iron depletion or increasing the iron pool inside the pathogen-containing cellular compartments to enhance ROS production. Recently, it has been proved that Fpn is required to provide iron to Salmonella-containing vacuoles (SCVs), where iron plays a key role as a co-factor in ROS generation [48]. A similar ROS-dependent mechanism driven by copper and the potential role of copper as an enhancer of Fpn expression under inflammatory states need to be confirmed and require further investigation.

Besides the transcriptional level, Fpn expression is controlled on the translational and systemic level. Here, in contrast to the transcriptional upregulation of $\mathrm{Fpn}$ after $\mathrm{CuCl}_{2}$ treatment, we did not observe significantly increased Fpn protein levels in the cellular extracts corresponding to the membrane fraction in primary macrophages. Interestingly, in our previous study focusing on the role of copper in maintaining iron homeostasis in mosaic mutant mice (Atp7a mutated gene leads to severe systemic disorder of copper metabolism), we observed a copper-dependent increase in both Fpn mRNA and protein abundance in bone-marrow-derived macrophages derived from wild-type control mice [49]. The discrepancy between studies regarding the regulation of $\mathrm{Fpn}$ after $16 \mathrm{~h}$ of $\mathrm{CuCl}_{2}$ stimulation 
is unclear; however, the use of different mouse strains (outbred colony vs. inbred C57Bl/6J) may contribute to the observed differences.

Moreover, here we observed that longer $\mathrm{CuCl}_{2}$ stimulation significantly decreased Fpn protein abundance, suggesting the involvement of cellular post-transcriptional or systemic post-translational control of Fpn expression. Hepcidin (Hamp) is the master regulator of iron homeostasis, which binds to Fpn and leads to its rapid internalization and degradation [4]. Hepcidin is mainly produced in the liver, but its expression increases in stimulated and pro-inflammatory macrophages and those infected with intracellular pathogens [35]. Our data confirm that primary bone-marrow-derived macrophages have the ability to produce hepcidin after LPS treatment, but copper exposure did not affect Hamp expression, suggesting that the latter mechanism is not responsible for the observed Fpn downregulation. The role of ceruloplasmin (Cp) - a copper-dependent ferroxidase that participates in the process of cellular iron efflux via the oxidation of $\mathrm{Fe}^{2+}$ to $\mathrm{Fe}^{3+}$-seems to be intriguing to reconcile as the potential factor contributing to the Fpn protein level. It has been shown previously that GPI-Cp (glycosylphosphatidylinositol (GPI)-anchored membrane form of $\mathrm{Cp}$ ) is able to physically interact with Fpn localized within astrocyte cellular membranes, which in the absence of GPI-Cp was not able to efflux iron, and this suggests that Cp may impact the function or stability of Fpn [50]. However, these findings require further investigations.

Interestingly, copper loading did not alter macrophage ferritin levels (both light and heavy chains), suggesting that the decrease in Fpn was not sufficient to increase intracellular iron levels, at least to the extent required to stimulate ferritin synthesis. $\mathrm{Moreover}, \mathrm{CuCl}_{2}$ treatment did not affect TfR1 mRNA expression, the level of which is highly dependent on cellular iron content and regulated by the interaction of IRPs with IRE sequences localized within the $3^{\prime}$ UTR of TfR1 mRNA [33]. These data are consistent with previous research on the J774 macrophage cell line showing that copper loading did not significantly influence TfR1 expression [10]. The IRE sequence is also localized within the 5 'UTR mRNA of Fpn, which could impair Fpn expression through translational repression [3]. Our data suggest that macrophage copper loading does not modify the IRE binding activity of IRPs, which allows us to rule out this post-transcriptional regulatory mechanism as potentially being responsible for decreased Fpn protein levels.

Our analysis showed that the expression levels of selected genes involved in the processes of protein ubiquitination $\left(U_{s p 14}, U b c\right)$, proteasomes (Psma1, Psmc4), and the subset of endosomes that contain membrane-bound intraluminal vesicle formation (Lip5,Chmp5) were not significantly altered by copper loading. As lysosomal degradation is thought to be responsible for Fpn degradation [4], we treated BMDMs with chloroquine (Chlq) to impair lysosomal function. Chlq interferes with the activity of lysosomes, interacts with their membrane stability, and alters their signaling pathways [51]. Surprisingly, Chlq treatment led to a significant decrease in Fpn abundance in the membrane fraction of BMDMs. However, when combined with $\mathrm{CuCl}_{2}$, it increased the ferritin protein level in the cytosolic fraction, which suggests that the downregulatory effect is limited to Fpn. Interestingly, in hepatocytes exposed to elevated copper levels, one of the copper transporters, Atp7b, moves from the Golgi to lysosomes and imports metal into their lumen [52]. Moreover, in vivo models of copper overload demonstrated that increased copper loading in the liver leads to increased activity of lysosomal enzymes and reduces their structural integrity [53]. These data allow us to speculate that in macrophages, copper treatment and the disruption of lysosomal function may exert somewhat similar effects, affecting the stability of Fpn in an iron-independent manner.

Finally, it seems that cell type specificity may be responsible for the regulation of Fpn protein abundance in response to copper loading. In contrast to BMDMs, in primary peritoneal macrophages, Fpn levels did not change after copper treatment. Interestingly, in the RAW 264.7 macrophage-like cell line, copper exposure led to significant time-dependent increases in Fpn expression at both the mRNA and protein level. These data are consistent with the previously reported copper-dependent regulation of Fpn expression in 
macrophage-like cell line J774, where $48 \mathrm{~h}$ stimulation with $\mathrm{CuSO}_{4}$ was shown to significantly increase Fpn protein levels [10].

There are important differences between primary macrophages and macrophage cell lines regarding their responses to stimuli, which were previously reported in bonemarrow-derived macrophages and J774 cells infected with Mycobacterium tuberculosis [54]. Moreover, macrophages are considered as a heterogeneous cell population whose phenotype changes in response to their microenvironment and stimuli where they can adopt to a functional M1 (pro-inflammatory) or M2 (anti-inflammatory) program [55]. Bisgaard et al. (2016) had shown that the inflammatory response of BMDMs and peritoneal macrophages differs significantly, where the mRNA expression of M1/M2 markers was higher in peritoneal macrophages than BMDMs [56]. Moreover, it was shown previously that particular biometals such as copper in lower dosage $(10 \mu \mathrm{M})$ are able to induce macrophage polarization towards an M2 phenotype, while higher concentrations $(100 \mu \mathrm{M})$ stimulate a pro-inflammatory M1 response [57]. The M1/M2 macrophage phenotype impacts Fpn levels, where Fpn was downregulated in M1 and upregulated in M2 macrophages [58,59]. However, we did not observe a significant switch from M1 or M2 macrophage phenotypes after $\mathrm{CuCl}_{2}$ treatment (data not shown), suggesting that other factors are responsible for the observed differences.

In macrophages, Fpn is localized within lipid rafts, specific cell membrane compartments enriched in cholesterol and sphingolipids [25]. These membrane domains play a pivotal role in a variety of cellular processes, including intracellular trafficking and cell signaling [60-62]. It was previously shown that iron loading strongly enhances Fpn abundance in the low-density raft fraction of BMDMs and J774 macrophages, and raft integrity is important for the interaction of hepcidin with macrophage Fpn [25]. Here, we also report significant Fpn abundance in the lipid raft-enriched membrane fraction of RAW macrophages after iron loading, confirmed by the presence of a raft marker, flotilin 2 [27]. Interestingly, the subcellular pattern of Fpn localization in RAW macrophages after copper treatment differs from that obtained as a result of exposure to iron. Although some part of Fpn was still associated with lipid rafts, a significant amount was localized within dense, non-raft-enriched fractions (confirmed by the presence of a non-raft membrane protein, TfR1). Copper regulates genes involved in the cholesterol biosynthetic pathway [63] and is able to induce the redistribution of protein associated with the lipid raft fraction toward non-raft domains [64]. Therefore, because the hepcidin-mediated regulation of Fpn in macrophages strictly relies on lipid raft-dependent endocytosis, the possible coppermediated influence on Fpn expression and cellular distribution seems to be interesting and worth investigating further.

\section{Conclusions}

In conclusion, we found that copper loading significantly enhances Fpn transcription in an Nrf2-dependent manner in primary bone-marrow-derived macrophages. Moreover, $\mathrm{CuCl}_{2}$ treatment affects Fpn expression in the RAW 264.7 macrophage-like cell line; however, cell-type-specific regulations seem to be involved in the processes connected to Fpn protein stability. In primary BMDMs, prolonged copper exposure led to a hepcidinand iron-independent decrease in Fpn protein abundance, which was not the case for the macrophage cell line. The impact of copper loading on lysosomal activity in primary macrophages requires further investigation. In the context of the pivotal role of Fpn and iron trafficking within macrophages during infection, our data suggest that copper treatment is able to counteract the LPS-induced transcriptional suppression of Fpn expression, which may reflect additional immunomodulative properties of copper.

Supplementary Materials: The following are available online at https: / www.mdpi.com/article/ 10.3390/cells10092259/s1, Table S1: List of primers for qPCR, Table S2: List of antibodies for Western blot. 
Author Contributions: Conceptualization, P.L. and A.J.; methodology, A.J. and R.M.; formal analysis, A.J., P.L. and R.R.S.; investigation, A.J., R.M., E.S., B.Ż. and Z.K.; data curation, A.J.; writingoriginal draft preparation, A.J.; writing - review and editing, A.J., P.L. and R.R.S.; visualization, A.J.; supervision, P.L.; project administration, A.J. and P.L.; funding acquisition, A.J. and P.L. All authors have read and agreed to the published version of the manuscript.

Funding: This research was funded by the National Science Centre, Poland (grant no. 2017/25/N/ NZ3/01957).

Institutional Review Board Statement: Not applicable.

Informed Consent Statement: Not applicable.

Data Availability Statement: All data supporting the findings of this research are available within the article or from the corresponding author upon request.

Acknowledgments: We thank Sylwester Smoleń (University of Agriculture, Cracow, Poland) for performing copper concentration measurements using ICP-MS, Piotr Poznański (Institute of Genetics and Animal Biotechnology PAS, Jastrzębiec, Poland) for critically reviewing the manuscript, and François Canonne-Hergaux (INSERM, Toulouse, France) for providing affinity-purified antiFpn antibody and crucial advice in protocols for Fpn detection in cellular membrane and lipids rafts extracts.

Conflicts of Interest: The authors declare no conflict of interest.

\section{References}

1. Drakesmith, H.; Nemeth, E.; Ganz, T. Review Ironing out Ferroportin. Cell Metab. 2015, 22, 777-787. [CrossRef] [PubMed]

2. Mleczko-Sanecka, K.; Silvestri, L. Cell-type-specific insights into iron regulatory processes. Am. J. Hematol. 2021, 96, 110-127. [CrossRef] [PubMed]

3. Lymboussaki, A.; Pignatti, E.; Montosi, G.; Garuti, C.; Haile, D.J.; Pietrangelo, A. The role of the iron responsive element in the control of ferroportin1/IREG1/MTP1 gene expression. J. Hepatol. 2003, 39, 710-715. [CrossRef]

4. Nemeth, E.; Tuttle, M.S.; Powelson, J.; Vaughn, M.B.; Donovan, A.; Ward, D.M.; Ganz, T.; Kaplan, J. Hepcidin Regulates Cellular Iron Efflux by Binding to Ferroportin and Inducing Its Internalization. Science 2004, 306, 2090-2094. [CrossRef] [PubMed]

5. Marro, S.; Chiabrando, D.; Messana, E.; Stolte, J.; Turco, E.; Tolosano, E.; Muckenthaler, M.U. Heme controls ferroportin1 (FPN1) transcription involving Bach1, Nrf2 and a MARE/ARE sequence motif at position -7007 of the FPN1 promoter. Haematologica 2010, 95, 1261-1268. [CrossRef] [PubMed]

6. Delaby, C.; Pilard, N.; Puy, H.; Canonne-Hergaux, F. Sequential regulation of ferroportin expression after erythrophagocytosis in murine macrophages: Early mRNA induction by haem, followed by iron-dependent protein expression. Biochem. J. 2008, 411, 123-131. [CrossRef] [PubMed]

7. Aydemir, F.; Jenkitkasemwong, S.; Gulec, S.; Knutson, M.D. Iron Loading Increases Ferroportin Heterogeneous Nuclear RNA and mRNA Levels in Murine. J. Nutr. 2009, 139, 434-438. [CrossRef]

8. Yang, F.; Wang, X.; Haile, D.J.; Piantadosi, C.A.; Ghio, A.J. Iron increases expression of iron-export protein MTP1 in lung cells. Am. J. Physiol. Lung Cell. Mol. Physiol. 2002, 283, 932-939. [CrossRef]

9. Troadec, M.B.; Ward, D.M.V.; Lo, E.; Kaplan, J.; de Domenico, I. Induction of FPN1 transcription by MTF-1 reveals a role for ferroportin in transition metal efflux. Blood 2010, 116, 4657-4664. [CrossRef]

10. Chung, J.; Haile, D.J.; Wessling-Resnick, M. Copper-induced ferroportin-1 expression in J774 macrophages is associated with increased iron efflux. Proc. Natl. Acad. Sci. USA 2004, 101, 2700-2705. [CrossRef]

11. Collins, J.F.; Knutson, M.D. Metabolic crossroads of iron and copper. Nutr. Rev. 2013, 68, 133-147. [CrossRef] [PubMed]

12. Navegantes, K.C.; Gomes, R.D.S.; Aparecida, P.; Pereira, T. Immune modulation of some autoimmune diseases: The critical role of macrophages and neutrophils in the innate and adaptive immunity. J. Transl. Med. 2017, 15, 1-21. [CrossRef]

13. Gammella, E.; Buratti, P.; Cairo, G.; Recalcati, S. Macrophages: Central regulators of iron balance. Metallomics 2014, 6, $1336-1345$. [CrossRef] [PubMed]

14. Willemetz, A.; Beatty, S.; Richer, E.; Rubio, A.; Auriac, A.; Milkereit, R.J.; Thibaudeau, O.; Vaulont, S.; Malo, D.; Canonne-Hergaux, F. Iron- and hepcidin-independent downregulation of the iron exporter ferroportin in macrophages during Salmonella infection. Front. Immunol. 2017, 8, 498. [CrossRef]

15. Weiss, G.; Ganz, T.; Goodnough, L.T. Anemia of inflammation. Blood 2019, 133, 40-50. [CrossRef]

16. Ganz, T.; Nemeth, E. Iron Sequestration and Anemia of Inflammation. Semin. Hematol. 2009, 46, 387-393. [CrossRef]

17. Sweet, M.J.; Hume, D.A. Endotoxin signal transduction in macrophages. J. Leukoc. Biol. 1996, 60, 8-26. [CrossRef] [PubMed]

18. Ludwiczek, S.; Aigner, E.; Theurl, I.; Weiss, G. Cytokine-mediated regulation of iron transport in human monocytic cells. Blood 2003, 101, 4148-4154. [CrossRef] 
19. Harada, N.; Kanayama, M.; Maruyama, A.; Yoshida, A.; Tazumi, K.; Hosoya, T.; Mimura, J.; Toki, T.; Maher, J.M.; Yamamoto, M.; et al. Nrf2 regulates ferroportin 1-mediated iron efflux and counteracts lipopolysaccharide-induced ferroportin 1 mRNA suppression in macrophages. Arch. Biochem. Biophys. 2011, 508, 101-109. [CrossRef]

20. Bo, S.; Durazzo, M.; Gambino, R.; Berutti, C.; Milanesio, N.; Caropreso, A.; Gentile, L.; Cassader, M.; Cavallo-perin, P.; Pagano, G. Associations of Dietary and Serum Copper with Inflammation, Oxidative Stress, and Metabolic Variables in Adults. J. Nutr. 2008, 138, 305-310. [CrossRef] [PubMed]

21. Malavolta, M.; Piacenza, F.; Basso, A.; Giacconi, R.; Costarelli, L.; Mocchegiani, E. Serum copper to zinc ratio: Relationship with aging and health status. Mech. Ageing Dev. 2015, 151, 93-100. [CrossRef] [PubMed]

22. Achard, M.E.S.; Stafford, S.L.; Bokil, N.J.; Chartres, J.; Bernhardt, P.V.; Schembri, M.A.; Sweet, M.J.; McEwan, A.G. Copper redistribution in murine macrophages in response to Salmonella infection. Biochem. J. 2012, 444, 51-57. [CrossRef]

23. White, C.; Lee, J.; Kambe, T.; Fritsche, K.; Petris, M.J. A Role for the ATP7A Copper-transporting ATPase in Macrophage Bactericidal Activity. J. Biol. Chem. 2009, 284, 33949-33956. [CrossRef]

24. Ray, A.; Dittel, B.N. Isolation of mouse peritoneal cavity cells. J. Vis. Exp. 2010, 9-11. [CrossRef]

25. Auriac, A.; Willemetz, A.; Canonne-Hergaux, F. Lipid raft-dependent endocytosis: A new route for hepcidin-mediated regulation of ferroportin in macrophages. Haematologica 2010, 95, 1269-1277. [CrossRef] [PubMed]

26. Marques, L.; Auriac, A.; Willemetz, A.; Banha, J.; Silva, B.; Canonne-Hergaux, F.; Costa, L. Immune cells and hepatocytes express glycosylphosphatidylinositol-anchored ceruloplasmin at their cell surface. Blood Cells Mol. Dis. 2012, 48, 110-120. [CrossRef] [PubMed]

27. Sasaki, Y.; Oshima, Y.; Koyama, R.; Maruyama, R.; Akashi, H.; Mita, H.; Toyota, M.; Shinomura, Y.; Imai, K.; Tokino, T. Identification of flotillin-2, a major protein on lipid rafts, as a novel target of p53 family members. Mol. Cancer Res. 2008, 6, 395-406. [CrossRef]

28. Harder, T.; Scheiffele, P.; Verkade, P.; Simons, K. Lipid domain structure of the plasma membrane revealed by patching of membrane components. J. Cell Biol. 1998, 141, 929-942. [CrossRef]

29. Mutter, F.E.; Park, B.K.; Copple, I.M. Value of monitoring Nrf2 activity for the detection of chemical and oxidative stress. Biochem. Soc. Trans. 2015, 43, 657-662. [CrossRef]

30. Liu, X.B.; Nguyen, N.B.H.; Marquess, K.D.; Yang, F.; Haile, D.J. Regulation of hepcidin and ferroportin expression by lipopolysaccharide in splenic macrophages. Blood Cells Mol. Dis. 2005, 35, 47-56. [CrossRef]

31. Harrison, P.M.; Arosio, P. The ferritins: Molecular properties, iron storage function and cellular regulation. Biochim. Biophys. Acta-Bioenerg. 1996, 1275, 161-203. [CrossRef]

32. Mesquita, G.; Silva, T.; Gomes, A.C.; Oliveira, P.F.; Alves, M.G.; Fernandes, R.; Almeida, A.A.; Moreira, A.C.; Gomes, M.S. H-Ferritin is essential for macrophages' capacity to store or detoxify exogenously added iron. Sci. Rep. 2020, 10, 1-15. [CrossRef] [PubMed]

33. Casey, J.L.; Hentze, M.W.; Koeller, D.M.; Wright Caughman, S.; Rouault, T.A.; Klausner, R.D.; Harford, J.B. Iron-responsive elements: Regulatory RNA sequences that control mRNA levels and translation. Science 1988, 240, 924-928. [CrossRef] [PubMed]

34. Kühn, L.C. Iron regulatory proteins and their role in controlling iron metabolism. Metallomics 2015, 7, 232-243. [CrossRef] [PubMed]

35. Sow, F.B.; Florence, W.C.; Satoskar, A.R.; Schlesinger, L.S.; Zwilling, B.S.; Lafuse, W.P. Expression and localization of hepcidin in macrophages: A role in host defense against tuberculosis. J. Leukoc. Biol. 2007, 82, 934-945. [CrossRef]

36. Mckie, A.T.; Marciani, P.; Rolfs, A.; Brennan, K.; Wehr, K.; Barrow, D.; Miret, S.; Bomford, A.; Peters, T.J.; Farzaneh, F.; et al. A Novel Duodenal Iron-Regulated Transporter, IREG1, Implicated in the Basolateral Transfer of Iron to the Circulation. Mol. Cell. 2000, 5, 299-309. [CrossRef]

37. Mulero, V.; Brock, J.H. Regulation of iron metabolism in murine J774 macrophages: Role of nitric oxide-dependent and independent pathways following activation with gamma interferon and lipopolysaccharide. Blood 1999, 94, 2383-2389. [CrossRef]

38. Knutson, M.; Wessling-resnick, M. Iron metabolism in the reticuloendothelial system. Crit. Rev. Biochem. Mol. Biol. 2003, 38, 61-88. [CrossRef] [PubMed]

39. Mitchell, C.J.; Shawki, A.; Ganz, T.; Nemeth, E.; Mackenzie, B. Functional properties of human ferroportin, a cellular iron exporter reactive also with cobalt and zinc. Am. J. Physiol Cell Physiol. 2014, 306, 450-459. [CrossRef]

40. Günther, V.; Lindert, U.; Schaffner, W. The taste of heavy metals: Gene regulation by MTF-1. Biochim. Biophys. Acta-Mol. Cell Res. 2012, 1823, 1416-1425. [CrossRef]

41. Ha, J.H.; Doguer, C.; Wang, X.; Flores, S.R.; Collins, J.F. High-iron consumption impairs growth and causes copper-deficiency anemia in weanling Sprague-Dawley rats. PLoS ONE 2016, 11, e0161033. [CrossRef] [PubMed]

42. Thackeray, E.W.; Sanderson, S.O.; Fox, J.C.; Kumar, N. Hepatic iron overload or cirrhosis may occur in acquired copper deficiency and is likely mediated by hypoceruloplasminemia. J. Clin. Gastroenterol. 2011, 45, 153-158. [CrossRef] [PubMed]

43. Ahmed, S.M.U.; Luo, L.; Namani, A.; Wang, X.J.; Tang, X. Nrf2 signaling pathway: Pivotal roles in inflammation. Biochim. Biophys. Acta-Mol. Basis Dis. 2017, 1863, 585-597. [CrossRef] [PubMed]

44. Stafford, S.L.; Achard, M.E.S.; Schembri, M.A.; Mcewan, A.G.; Sweet, M.J.; Bokil, N.J.; Kapetanovic, R. Metal ions in macrophage antimicrobial pathways: Emerging roles for zinc and copper. Biosci. Rep. 2013, 33, 541-554. [CrossRef] [PubMed]

45. Hood Indriati, M. Nutritional immunity: Transition metals at the pathogen-host interface. Nat. Rev. Microbiol. 2012, 10, 525-537. [CrossRef] [PubMed] 
46. Van Zandt, K.E.; Sow, F.B.; Florence, W.C.; Zwilling, B.S.; Satoskar, A.R.; Schlesinger, L.S.; Lafuse, W.P. The iron export protein ferroportin 1 is differentially expressed in mouse macrophage populations and is present in the mycobacterial-containing phagosome. J. Leukoc. Biol. 2008, 84, 689-700. [CrossRef] [PubMed]

47. Yang, F.; Liu, X.B.; Quinones, M.; Melby, P.C.; Ghio, A.; Haile, D.J. Regulation of reticuloendothelial iron transporter MTP1 (Slc11a3) by inflammation. J. Biol. Chem. 2002, 277, 39786-39791. [CrossRef]

48. Lim, D.; Kim, K.S.; Jeong, J.H.; Marques, O.; Kim, H.J.; Song, M.; Lee, T.H.; Kim, J.I.; Choi, H.S.; Min, J.J.; et al. The hepcidinferroportin axis controls the iron content of Salmonella-containing vacuoles in macrophages. Nat. Commun. 2018, 9, 1-12. [CrossRef] [PubMed]

49. Lenartowicz, M.; Starzyński, R.R.; Jończy, A.; Staroń, R.; Antoniuk, J.; Krzeptowski, W.; Grzmil, P.; Bednarz, A.; Pierzchała, O.; Ogórek, M.; et al. Copper therapy reduces intravascular hemolysis and derepresses ferroportin in mice with mosaic mutation (Atp7amo-ms): An implication for copper-mediated regulation of the Slc40a1 gene expression. Biochim. Biophys. Acta-Mol. Basis Dis. 2017, 1863, 1410-1421. [CrossRef]

50. Jeong, S.Y.; David, S. Glycosylphosphatidylinositol-anchored ceruloplasmin is required for iron efflux from cells in the central nervous system. J. Biol. Chem. 2003, 278, 27144-27148. [CrossRef]

51. Schrezenmeier, E.; Dörner, T. Mechanisms of action of hydroxychloroquine and chloroquine: Implications for rheumatology. Nat. Rev. Rheumatol. 2020, 16, 155-166. [CrossRef] [PubMed]

52. Polishchuk, E.V.; Concilli, M.; Iacobacci, S.; Chesi, G.; Pastore, N.; Piccolo, P.; Paladino, S.; Baldantoni, D.; van IJzendoorn, S.C.D.; Chan, J.; et al. Wilson Disease Protein ATP7B Utilizes Lysosomal Exocytosis to Maintain Copper Homeostasis. Dev. Cell. 2014, 29, 686-700. [CrossRef]

53. Abe, S.H.U. Impaired Lysosomal Rat Biliary Excretion of Copper and Enzymes in Long-Evans cinnamon. Tohoku J. Exp. Med. 1994, 172, 355-367. [CrossRef]

54. Andreu, N.; Phelan, J.; De Sessions, P.F.; Cliff, J.M.; Clark, T.G.; Hibberd, M.L. Primary macrophages and J774 cells respond differently to infection with Mycobacterium tuberculosis. Sci. Rep. 2017, 7, 1-12. [CrossRef]

55. Italiani, P.; Boraschi, D. From monocytes to M1/M2 macrophages: Phenotypical vs. functional differentiation. Front. Immunol. 2014, 5, 1-22. [CrossRef] [PubMed]

56. Bisgaard, L.S.; Mogensen, C.K.; Rosendahl, A.; Cucak, H.; Nielsen, L.B.; Rasmussen, S.E.; Pedersen, T.X. Bone marrow-derived and peritoneal macrophages have different inflammatory response to oxLDL and M1/M2 marker expression-Implications for atherosclerosis research. Sci. Rep. 2016, 6, 1-10. [CrossRef]

57. Díez-Tercero, L.; Delgado, L.M.; Bosch-Rué, E.; Perez, R.A. Evaluation of the immunomodulatory effects of cobalt, copper and magnesium ions in a pro inflammatory environment. Sci. Rep. 2021, 11, 1-13. [CrossRef]

58. Recalcati, S.; Locati, M.; Marini, A.; Santambrogio, P.; Zaninotto, F.; De Pizzol, M.; Zammataro, L.; Girelli, D.; Cairo, G. Differential regulation of iron homeostasis during human macrophage polarized activation. Eur. J. Immunol. 2010, 40, 824-835. [CrossRef]

59. Corna, G.; Campana, L.; Pignatti, E.; Castiglioni, A.; Tagliafico, E.; Bosurgi, L.; Campanella, A.; Brunelli, S.; Manfredi, A.A.; Apostoli, P.; et al. Polarization dictates iron handling by inflammatory and alternatively activated macrophages. Haematologica 2010, 95, 1814-1822. [CrossRef] [PubMed]

60. Le Roy, C.; Wrana, J.L. Clathrin- and non-clathrin-mediated endocytic regulation of cell signalling. Nat. Rev. Mol. Cell Biol. 2005, 6, 112-126. [CrossRef] [PubMed]

61. Simons, K.; Toomre, D. Lipid rafts and signal transduction. Nat. Rev. Mol. Cell Biol. 2000, 1, 31-39. [CrossRef] [PubMed]

62. Ouweneel, A.B.; Thomas, M.J.; Sorci-Thomas, M.G. The ins and outs of lipid rafts: Functions in intracellular cholesterol homeostasis, microparticles, and cell membranes. J. Lipid Res. 2020, 61, 676-686. [CrossRef] [PubMed]

63. Huster, D.; Purnat, T.D.; Burkhead, J.L.; Ralle, M.; Fiehn, O.; Stuckert, F.; Olson, N.E.; Teupser, D.; Lutsenko, S. High copper selectively alters lipid metabolism and cell cycle machinery in the mouse model of Wilson disease. J. Biol. Chem. 2007, 282, 8343-8355. [CrossRef] [PubMed]

64. Hung, Y.H.; Robb, E.L.; Voltakis, I.; Ho, M.; Evin, G.; Li, Q.X.; Culvenor, J.G.; Masters, C.L.; Cherny, R.A.; Bush, A.I. Paradoxical condensation of copper with elevated $\beta$-amyloid in lipid rafts under cellular copper deficiency conditions: Implications for Alzheimer disease. J. Biol. Chem. 2009, 284, 21899-21907. [CrossRef] [PubMed] 